УДК 355/359-5/-9

\title{
«УРОК МУЖЕСТВА: ПАМЯТИ АФГАНСКОЙ ВОЙНЫ ПОСВЯЩАЕТСЯ» КАК ФАКТОР ФОРМИРОВАНИЯ У МОЛОДОГО ПОКОЛЕНИЯ ЧУВСТВА ПАТРИОТИЗМА
}

\author{
Сидлецкий Дмитрий Мичиславович \\ магистр педагогических наук \\ педагог дополнительного образования \\ МБУ ДО гДДЮТ
}

Аннотация: Уроки нашей истории. Афганская война. Рассказы о наших солдатах, которым пришлось служить в Афганистане и участвовать в боевых действиях на чужбине. Как молодым ребятам пришлось на себе испытать все тяготы службы вдали от своей Родины.

Ключевые слова: Урок мужества, Афганская война, Александр Боровиков, «В июльском кошмаре», Дмитрий Бушов, Евгений Шумков, «Наша девятая рота».

\section{«A LESSON IN COURAGE: DEDICATED TO THE MEMORY OF THE AFGHAN WAR» AS A FACTOR IN THE FORMATION OF A SENSE OF PATRIOTISM AMONG THE YOUNGER GENERATION}

\section{Sidletsky Dmitry Michislavovich}

\begin{abstract}
The lessons of our history. The Afghan War. Stories about our soldiers who had to serve in Afghanistan and participate in combat operations in a foreign land. How young guys had to experience all the hardships of service away from their homeland.

Key words: Lesson of courage, Afghan war, Alexander Borovikov, "In a July nightmare", Dmitry Bushov, Evgeny Shumkov, "Our ninth company".

Тема этой программы зародилась давно, когда тагильчане стали возвращаться из Афганистана домой, и из них - 21 в цинковом гробу.

В школьной программе по истории кратко говорится о войне 1812 года, поэтому современное поколение знает Героев тех времён только по


картинкам. А о локальных войнах, в которых участвовали наши парни, вообще стараются умалчивать - итог плачевный, исторические факты вытеснены современными компьютерными играми. Материал про подвиги нашего народа на данный момент слишком сокращён или отодвинут даже не на второй план, а, вероятно, ещё дальше. На сегодняшний день обширную деятельность проявляет программа РДШ (Российское движение школьников), но многие педагоги считают, что этому направлению надо вернуть любовь к школам, к истории нашей страны, а не дублировать, к примеру, проведение игры «Зарница» и тому подобные мероприятия. Для этих программ есть другие общественные патриотические организации - например: Ветераны войны, Афганского движение или «Боевое братство», ДОСААФ и т.д. которым эта тема ближе, а профессиональный подход этими объединениями делают игры качественнее.

Нашим воспитанникам неоднократно приходилось участвовать на сборах областного уровня и Всероссийского значения, на которых задавался один и тот же вопрос: «Скоро Вам в школу, поднимите руки кто ждёт 1-е сентября и у кого есть желание окунуться в мир знаний?» - ответ печальный, к примеру: из 500 присутствующих руки поднимают 3-4 человека, а ведь школа всегда была вторым домом. Из выше сказанного вывод один: надо вернуть ту программу обучения, которая считалась лучшей в Мире, но с учётом современного научного прорыва в области науки, РДШ должно быть первым помощником в разработке такой программы для общеобразовательных школ.

Мне часто говорят: о каком патриотизме ты говоришь, всё развалено, нет у народа уверенности в будущем нашего Государства, а молодёжь потеряна? Но я с такими пессимистами не согласен: мы и только мы должны воспитать честное, культурное, не коррумпированное поколение, которое придёт и будет управлять нашей страной.

Здравствуйте, молодые люди, курсанты, учащиеся и студенты!

Сегодня я проведу у вас урок мужества, который посвящается событиям Афганской войны, длившейся почти 10 лет с 27 декабря 1979 года до вывода советских войск из ДРА (Демократической республики Афганистан) 15 февраля 1989 года.

Давайте познакомимся. Меня зовут Дмитрий Мичиславович Сидлецкий. Я являюсь руководителем Военно-патриотического клуба «Гранит» (МБУ ДО «Городской Дворец детского и юношеского творчества» - ДОСААФ России) города Нижний Тагил. Этот клуб является одним из старейших в городе 
«Трудовой Доблести». Наш ВПК был создан 20 декабря 1982 года, и в этом 2021 году ему исполнилось 39 лет.

Имею два высших образования: 1-е - это УМЛ (Университет Марксизма-Ленинизма), сейчас вернули ему прежнее название УНХ (Университет народного хозяйства), по теме - хозяйственные руководители высшего и среднего звена, 2-е - это УрГПУ (Уральский государственный Педагогический Университет, ФБЖ - факультет безопасности жизнедеятельности), Магистр педагогических наук. Декан факультета - Репин Юрий Александрович, один из организаторов этого вида педагогического образования в Советском Союзе.

\section{Итак, к теме:}

Этот 2-х часовой Урок мы разделим на 4 части. В первой мы просмотрим документальный фильм об Афганистане, который называется «Последний солдат» (авторы сценария: Пётр Силантьев, Александр Ляховский, режиссёр: Сергей Серёгин). В фильме ведётся рассказ о том, как шла борьба между «кланами» за власть в Афганистане, и о том, почему Правительство СССР (Союз Советских социалистических Республик) решило ввести наши войска на территорию ДРА (демократическая республика Афганистан).

Во второй - вы прослушаете мой очерк, напечатанный в газете «Тагильский рабочий» от 25 декабря 2014 года, который называется «В июльском кошмаре» [c.5]. В нём ведётся рассказ о нашем земляке, Боровикове Александре, на долю, которого выпало служить в «Афгане» и участвовать в боевых действиях на чужбине. Как девятнадцатилетнему парню пришлось на своей «шкуре» испытать все тяготы службы вдали от своей Родины, быть тяжело раненым и оставаться истинным патриотом своей страны.

В третьей части мы организуем встречу с самим Александром Боровиковым, который, не смотря на свою инвалидность (потеря обеих ног), приедет к нам на встречу, и вы сможете поговорить с ним о восьмидесятых годах прошлого века, и задать ему интересующие вас вопросы.

В четвёртой - посетим «Музей памяти воинов-тагильчан, погибших в локальных войнах планеты», который является одним из лучших в России.

А сейчас возьмите ручки и листочки для того, чтобы Вы смогли для себя записать интересующие вас вопросы во время просмотра фильма, а потом я постараюсь ответить на них. 


\section{Итак, начинаем.}

Ознакомление присутствующих с программой проведения «урока мужества» по программе Дополнительного образования МБУ ДО ГДДЮТ (Городского Дворияа детского и юношеского творчества) - «Наследники победын.

- показ ролика об участии советских войск в Афганской войне «Последний солдат»;

- читается текст очерка "В июльском кошмаре» [c. 5], газета «Тагильский рабочий», № 240 (24129) от 25 декабря 2014 года, стр.7;

- встреча с Александром Боровиковым, участником событий, описанных в очерке;

- посещение Музея памяти воинов-тагильчан, погибших в локальных войнах планеты», где находится стенд Военно-патриотического клуба «ранит».

- Домашнее задание присутствующчм - Написать статью об участниках боевых действий в ДРА с прослушиванием статьи, опубликованной в «Федеральной газете-24», - «наша девятая рота» от 22.05.2020 г [c. 11].

По возвращении в аудиторию запишите домашнее задание:

Найдите человека, участника боевых действий в ДРА (из родственников, соседей, знакомых) и совместно с ним опишите его биографию.

\section{Примерные вопросы:}

1) Где родился; 2) Чем занимался до прохождения службы; 3) Как и где проходила служба в Вооруженных силах; 4) Как сложилась судьба до сегодняшнего дня.

Через 2 месяца, в феврале, ко Дню вывода войск из ДРА (15 февраля) принесите домашнюю работу, и мы вместе рассмотрим выполнение вашего задания. Не надо бояться оценивающего результата - мы один коллектив и должны помогать друг - другу правильно разбираться в данных ситуациях теоретически. К примеру, можно взять мою статью о нашем тагильчанине Дмитрии Бушове «Наша девятая рота», вышедшую в «Федеральной газете-24» [с.11]. В статье сослуживец Дмитрия - Евгений Шумков вспоминает о совместной дружбе-службе с ним до Афганистана, и до того незабываемого декабрьского дня, когда Дмитрон (так звали Дмитрия друзья в роте) погиб. Прочитав обе статьи, постарайтесь сделать для себя вывод, 
каково приходилось нашим ребятам служить там, за «речкой», в чужой стране под названием Афганистан.

До встречи с Вами в этой аудитории.

\section{В ИЮЛЬСКОМ КОШМАРЕ}

С Александром Боровиковым (рис.1) я познакомился в 1989 году. В то время мне по долгу работы пришлось встречать его в Москве, куда он прибывал из Чехословакии, где проходил повторную реабилитацию и протезирование. Тогда разговор с ним о ранении не получился, да и не хотелось тревожить его воспоминаниями. И вот, спустя много лет, мы вновь с ним повстречались - на полевых сборах с курсантами военно-патриотического клуба "Гранит», и я попросил рассказать Александра об Афганистане, где ему пришлось служить в начале 80-х, а точнее - с 1983-го по 1985 год.

Повестку тогда мне вручил водитель «скорой», - начал свой рассказ Александр. - По-видимому, перед ним поставили задачу собрать в военкомате всех допризывников, которые прошли спецподготовку и имели не менее трех прыжков с парашютом. Так с 13 октября 1983 года началась моя армейская жизнь. Она включила в себя и «учебку» в Фергане, и провинцию Баграм, куда нас забросили на Ил-76 для прохождения службы.

В Баграме меня определили в первый взвод связи 345-го отдельного парашютно-десантного гвардейского полка. Тогда-то мне как самому крепкому бойцу и вручили рацию Р-107 весом 21 килограмм, с которой пришлось передвигаться почти до окончания службы.

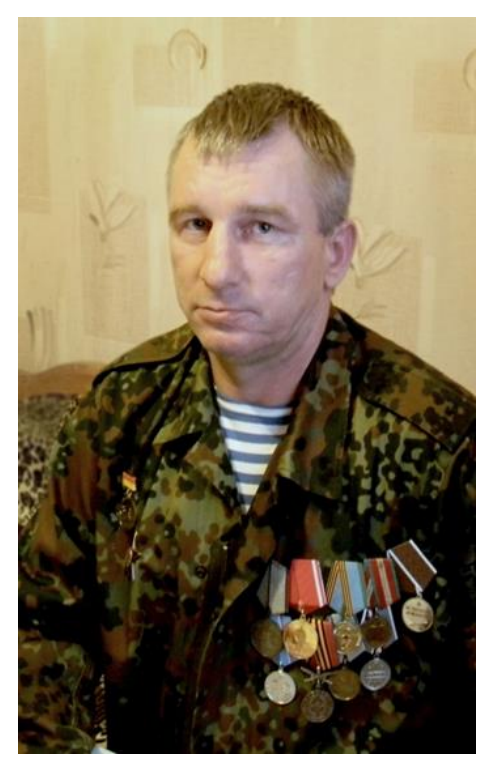

Рис. 1. Александр Боровиков 
Я хорошо помню, как мы проводили первую операцию в провинции Ургун. Полтора месяца проторчали в горах, в снегу, в засадах, находясь среди пуштунских племен. Смысл операции заключался в том, чтобы захватить или уничтожить бандитов, которые вырывались из окружения после «зачистки» аулов, проведенной пехотой. Многим моджахедам удавалось убегать в горы, где мы их вылавливали.

Один раз нас на «вертушках» забросили на гребень горы, ближе к вершине, и мы оказались наедине с суровой природой Афганистана. Первую ночь пережили с трудом. Из-за темноты не подготовили ночлежки и спали почти на снегу, укрывшись бронежилетами. На следующий день в двухметровом снегу вырыли схроны до камней, и жизнь сразу показалась прекрасной. Можно было развести костер, разогреть сухой паек, в который входили мясные консервы с перловкой и гречкой. Когда в такую кашу добавишь полбулки сухарей, то получается сытная «вкуснятина», я до сих пор не могу забыть этот вкус.

После операции в Ургуне нас перебросили в Пешегору в шести километрах от Пакистана. Поразило то, что после гор, холода и снега, буквально спустившись на километр в низину, мы попали в «зеленку», где было тепло, росли кедры. Позже, когда обжились, познакомились с царандоевцами - солдатами внутренних войск МВД ДРА. С ними стали обмениваться «сухпайками»: у них пайки болгарские - картошка, фасоль, горох с мясом, а у нас перловка с мясом. Тогда мы поняли разницу: какое питание у солдат войск Афгана и какое - у советских солдат.

Еще часто вспоминаю, как в 1984 году во время армейской операции нам нужно было колонной передвигаться по ущелью. Там нас обстреляли со всех сторон душманы. Бой был недолгим, прозвучала команда «По машинам!» Мы заскочили в БТРы и, уходя от огня, отъехали на полтора километра в долину. Тогда в неразберихе я оказался в первых машинах и побежал искать свой взвод в конец колонны. На обочине увидел сидящего Стаса Голубкова, он рыдал. Погиб земляк из Салды - Александр Мясников. Так мы понесли первую потерю в нашем взводе.

Вспоминается наша третья операция - в провинции Черекар. Перед нами была поставлена задача: прочесать кишлак. Зайдя в него, обнаружили только дымящиеся костры, на которых в казанах был разогретый плов, чай. Доносились детские голоса. Как только комбат решил доложить, что никто не обнаружен, началась стрельба, над головами прошли пулеметные и 
автоматные очереди. Комбат приказал нам заскочить в дом и занять оборону. Я оказался на втором этаже, где меня, как радиста, прикрывали товарищи. После очередной перестрелки, когда наступило кратковременное затишье, послышался крик: «Тагильчанина Димку Корякова ранили!» У меня до сих пор перед глазами стоит та картина: бойцы спускают его по лестнице в плащпалатке, голова свисает и вся в крови... Обратно из окружения нашей роте пришлось прорываться к боевой технике с боем.

Путь, который недавно был пуст и безлюден, при возвращении показался адом. Отходя и проходя между дуванами (глинобитными стенами), душманы расстреливали нас почти в упор. Более опытные бойцы выдвинулись вперед и стали забрасывать гранатами участки, откуда велся огонь. После каждого взрыва гранаты мы перебежками от калитки к калитке добрались до своих БТРов, на которых, отстреливаясь, удалились от кишлака, тем самым избежав больших потерь.

В том июльском кошмаре нашу роту сильно потрепало, да и ротой ее было трудно назвать. В строю постоянно человек 40-50, а остальные находились в расположении базы - или раненые, или болели желтухой, одним словом, небоеспособны.

Через пять дней после этих событий, 28 июля 1984 года, нам сообщили, что от полученных ран скончался заместитель командира взвода гвардии сержант Дмитрий Коряков, 1964 года рождения. Впоследствии он был награжден медалью «За боевые заслуги» и орденом Красной Звезды (посмертно).

Александр прикрыл глаза, видимо, вспоминая еще что-то, и через мгновение сказал:

- На этих операциях так набегаешься, что даже не помнишь, где и в каком месте они проходили, но события одного боя я помню четко.

После нового 1984 года едем по ущелью. Впереди воет «Урал», груженный сухим пайком, а за ним - вся наша колонна, которую замыкал танк. И никто не заметил, как перед колонной выскочил душман и из гранатомета подбил впереди идущую машину. Вот тут-то все и началось. Со склонов ущелья, словно рой диких пчел, на нас полетели пули и снаряды гранатометов. Обстрел был настолько плотный, что в первое мгновение мы не могли поднять головы.

Когда я опомнился и стал налаживать связь по рации, то увидел прикрывающего меня Славку Шувикова из Кургана, который пулеметным 
огнем вперемежку с отборным матом давил огневые точки бандитов. В тот момент своими действиями он спас не только мою жизнь, но и дал товарищам возможность сосредоточиться, чтобы они вели прицельный огонь по моджахедам. Воспользовавшись небольшим огневым затишьем, танк сопровождения выдвинулся к застрявшей технике и столкнул ее на обочину. После расчистки дороги прозвучала команда «По машинам!», и мы выскочили из ущелья. Добравшись до первого блокпоста, на котором стоял наш расчет, стали считать свои потери. Результат был неутешительным: много убитых и более десятка раненых, в их числе грузом «300» стал Славка из Курска, которому во время отхода пуля пробила плечо. Он до сих пор такой же сильный духом и смелый. Недавно проездом был у меня, и мы вспоминали нашу службу «за речкой». На мой взгляд, он даже не изменился.

Эти дни никогда не уйдут из памяти, они стали для меня роковыми. Командование поставило перед нами задачу организовать набор в афганскую армию из числа уклонистов, которые прячутся у себя в кишлаках. Рядом с нашим батальоном находились кишлаки, над одним из них возвышался красный флаг - значит это наш объект. Совместно с царандоевцами мы набрали в нем беглецов, зачитали им приказ о долге перед своей Родиной и отправили к своим в центр, а сами решили переночевать в этом кишлаке.

Утром 13 марта 1985 года, возвращаясь в расположение, я не думал, что все так обернется. Мне пришлось идти в колонне шестым. И вдруг - хлопок. В голове одна мысль - только бы не противопехотная мина, лишь бы не она... Очнулся, сижу в воронке, руки в крови, гляжу - нет на мне сапог, нет правой ноги, левую ногу приподнял - голеностоп болтается. Ко мне тут же подбежали, поставили два укола пирамидона и оказали медпомощь. Очень хотелось пить, и меня напоили, потом в палатке дотащили до точки, где села «вертушка», положили в нее, и я вырубился.

Очнувшись, увидел людей в белых халатах. Ко мне подбежал военврач и спросил, где у меня гранаты. Я показал на «разгрузку» (жилет для переноски боеприпасов). И как только гранаты достали, сразу разрезали на мне одежду, обтерли кровь и грязь на теле и стали оперировать. Я попросил хирурга, чтобы он оставил хотя бы одну ногу, на что тот ответил - сделаем все, что в наших силах. Не помню, сколько длилась операция. Придя в себя после наркоза, я откинул простыню и увидел, что нет обеих ног.

Вот тогда у меня началась душевная паника. В 20 лет инвалид, а вся жизнь еще впереди. Медсестра, увидев мое состояние, позвала хирурга, 
который попытался меня утешить. Приводил в пример Маресьева, который не только продолжал летать, но и научился танцевать.

Из-за тяжелого ранения я пролежал в нашем полковом госпитале неделю, только на седьмые сутки за мной прилетел специализированный Ан-2 и меня доставили в Союз, в ташкентский госпиталь. Оттуда - на спасательном Ил-76 - в рижский военный госпиталь. После осмотра моих ранений заведующий отделением Лев Борисович приказал сестрам срочно сделать перевязку, так как у меня в левой ноге находилось много осколков и раны кровоточили.

В госпитале на ежедневных перевязках бинты с моих ран срывали, как говорится, живьем. И только после того, как пожилая сестра милосердия Людмила Григорьевна узнала, что я, как и она, уроженец Нижнего Тагила, перевязки стали проводиться после примочек и почти безболезненно.

Людмила Григорьевна рассказала мне, что во время Великой Отечественной войны ушла на фронт, а после ее окончания вышла замуж и осталась с мужем в Риге (фамилии медработников Александр вспомнить не смог. - Прим. авт.)

Мое лечение шло тяжело и утомительно. И тут как приговор - гангрена на левой ноге. Срочно сделали операцию, отрезали еще 1,5 см кости, что и спасло меня от общего заражения крови.

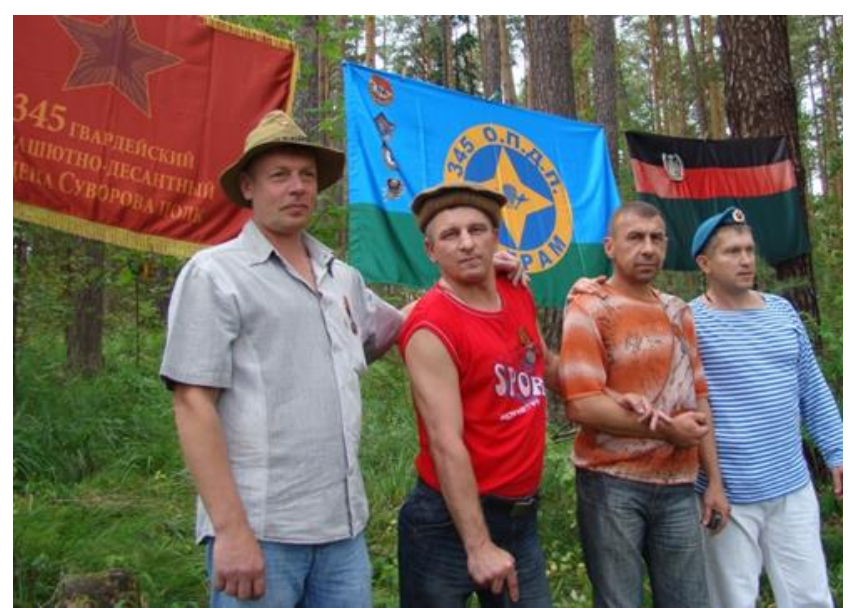

Рис. 2. Ветераны войны в ДРА 345 полка при встрече с курсантами ВПК «Гранит» на полевых сборах в пос. Антоновский, город Нижний Тагил (второй слева Боровиков Александр)

Когда очнулся и стал отходить от наркоза, то проклял все на свете. От боли три дня не мог найти себе места. Днем орал благим матом, так что 
даже больные выходили из палаты, а по ночам, стиснув зубы, стонал, уткнувшись в подушку. Только на четвертые сутки боль утихла.

В рижском госпитале я пролежал пять месяцев и 29 августа 1985 года был уже дома, в Нижнем Тагиле.

За участие в боевых действиях на дорогах афганской земли Александр Боровиков награжден орденом Красной Звезды и медалью «За отвагу».

Даже спустя много лет Александр до сих пор занимается патриотическим воспитанием подрастающего поколения и встречается с молодёжью (рис. 2).

\section{Дмитрий СИДЛЕЦКИЙ, руководитель ВПК «Гранит». \\ Консультант:}

Середа Владислав Антонович, полковник запаса, кандидат педагогических наук, доцент. участник боевых действий в ДРА ФОТО ИЗ ЛИЧНОГО АРХИВА

А. БОРОВИКОВА

\section{НАША ДЕВЯТАЯ РОТА \\ С Евгением Шумковым (рис.3) мы познакомились в военном} госпитале за Белой речкой в Екатеринбурге, где по случаю судьбы лежали в одной палате.

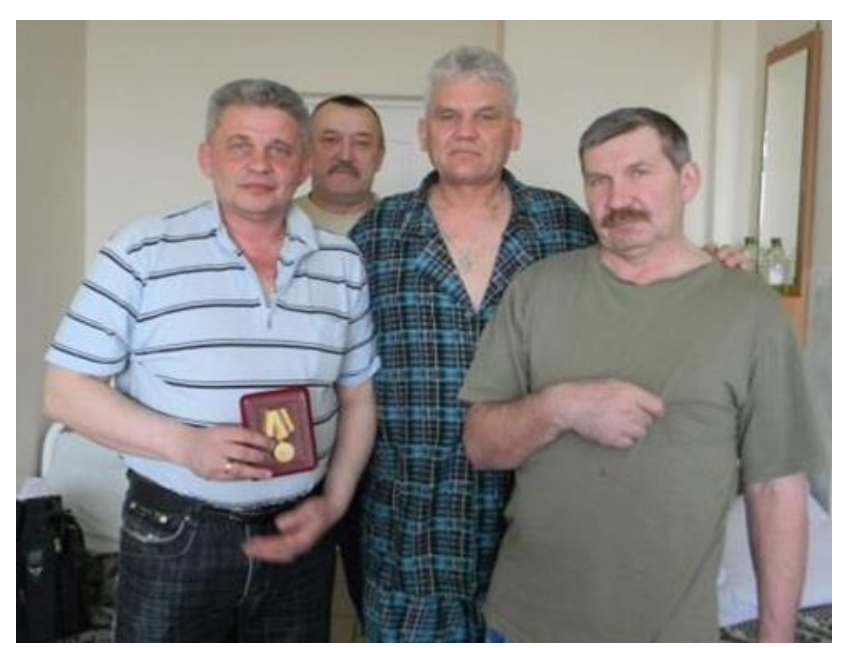

Рис. 3. Участники боевых действий в ДРА, проходящие реабилитацию в областном госпитале ветеранов войн, справа - Евгений Шумков

С ним быстро сдружились или, как говорится, нашли общий язык. Он много рассказывал о войне в Афганистане, где ему пришлось служить в 
1985 - 1986 годах прошлого столетия, и, когда он узнал, что я из Нижнего Тагила, сразу задал вопрос: «А ты Димку Бушова знал?» Мой ответ был: «Он погиб 15 декабря 1986 года под Кандагаром, у нас в Тагиле многие знают о бойцах, погибших на дорогах Афгана».

Нижнетагильским отделением Союза ветеранов Афганистана под председательством Виктора Бабенко, была выпущена книга «Прерванный полёт». Она посвящена погибшим в локальных войнах тагильчанам. В их числе более двадцати парней, не вернувшихся оттуда, а на пилонах памятника «Брод в неизвестность», что на берегу тагильского пруда (автор народный художник А.Г. Неверов), их имена вылиты из бронзы.

После долгого молчания, сжимая зубы и водя желваками, Евгений выдохнул: «А ведь он погиб на моих глазах», - и рассказал свои воспоминания о первой и последней встрече с Дмитроном - так его звали сослуживцы.

Мы познакомились с ним в танковом училище, куда нас привезли из Сборного пункта «Егоршино». Там, как и везде, нас определили на карантин. Там же нас переодели в военную форму и мы все стали на одно лицо.

Вечером, выдвигаясь в столовую, я увидел, как трое упитанных новобранцев зажали в углу худенького сослуживца и стали его избивать, но моё воспитание и мой девиз «никогда не обижать слабых» дали о себе знать и в итоге все обидчики лежали пластом на полу.

После этого случая в учебке города Иолотань Марыйской области Туркменистана, мы с Дмитроном стали армейскими друзьями. Там мы прожили три с половиной месяца, и ещё полтора месяца в горном учебном центре Келята под Ашхабадом, в котором нас обучали быть наводчиками пулемёта БТРа, правда, из крупнокалиберного танкового пулемёта стреляли всего раз, но зато там учили воевать в горах, и эти навыки потом пригодились в Афганистане.

И вот 19 февраля 1986 года нас на ТУ-154 в количестве 160 бойцов перебросили из Ашхабада в Кандагар, в 70-й Гвардейский орденов Кутузова и Богдана Хмельницкого мотострелковый полк. И сразу после прилёта всех распределили, и мы с Димкой попали в 3-й батальон 9-й роты.

Там проходили спец.подготовку, и только 31 мая нас забросили на точку. Задача перед нами, на первый взгляд, стояла обычная: если шла колонна, то мы её на БТРах сопровождали... Но это на первый взгляд, а если посмотреть глубже - то это ежедневная игра со смертью. 
Вот несколько случаев, которые быстро развеют впечатление о лёгкости работы, которую мы выполняли...

В феврале бойцы подразделения поехали в сопровождение. Я в тот момент был на заставе за КПВС (станковый). Вижу: «духи» устроили перед нашей заставой засаду и начали обстреливать из гранатомётов и стрелкового оружия БТРы сопровождения.

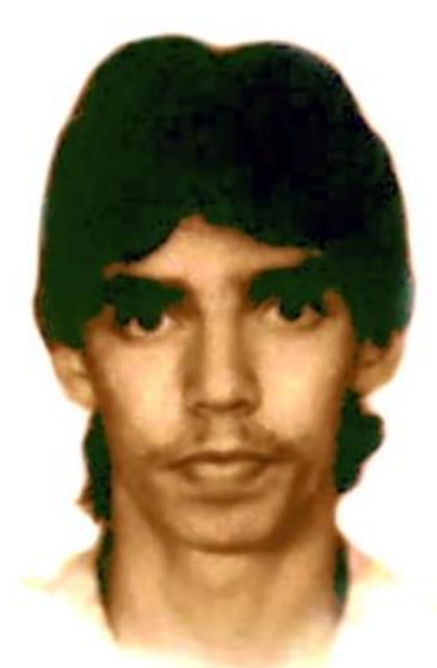

\section{Рис. 4. Бушов Дмитрий}

Сергей Латышев из Тверской области пытался укрыться на своей машине за горевший танк, и в этот момент с другой стороны выскочил душман и из гранатомёта прямо в упор выстрелил туда, где находился смотровой триплекс, и ему снесло полголовы. В том бою погибло два человека - Серёга и узбек Ореф Исмаилов, а ещё двоих, находившихся с ними, тяжело ранило. Только после мощного обстрела с нашей стороны духи тогда скрылись.

Был еще такой случай... При сопровождении очередной колонны перед нами шли сапёры, «процеживали» обочины, и в метрах 6-ти от нашего БТРа произошёл взрыв... По-видимому, сапёр Валера Кочкарёв щупом задел безоболачную мину. Когда пыль от взрыва осела, мы увидели изуродованное тело Валерки, а его автомат лежал в 20-ти метрах от него.

Хорошо помню один жестокий случай зимой в декабре... Один из наших БТРов сломался, все другие встали за ним, и в этот момент появились духи и стали в упор расстреливать нашу технику. Помню, что кое-как отстояли машину после продолжительного боя. В том бою погибли сапёр Равиль Нургоманов из Казани, а молдаванин Ионел был тяжело ранен. 
Или ещё такой случай... Пришёл из кишлака старейшина с сыномпереводчиком, который проходил обучение в Ташкенте, и сообщили, что дорогу, которая была под нашей охраной, заминировали. Мы оперативно выдвинулись к месту, указанному стариком на карте.

Удивительно, как духи смогли за ночь сделать подкоп под дорогу и заложить фугас (авиабомбу). Минёры, обследовав её, приняли решение уничтожить на месте. Потом воронку от взрыва нам пришлось засыпать два дня...

Всё это я рассказал для того, чтобы было понятно, с чем мы с Димкой каждодневно сталкивались... А наша застава находилась перед въездом в Кандагар на месте бывшего кишлака Биндиган, где нас каждый день обстреливали с зелёнки из миномётов и эрэсами, днём раз двадцать, ночью реже - всего раза по три - по четыре...

Я всё время считал, что Димка в рубашке родился... И вот пример: стояли мы как-то в сопровождении на Чёрной площади у Кандагара. Он выскочил из БТРа и хотел отойти, но сапёры крикнули ему: «Стой!», - и указали на противопехотную мину, которая находилась в 5 см от его ноги... Ещё бы немного - и всё. После этого он стал внимательно смотреть под ноги.

Перед тем как продолжить свой рассказ, Евгений присел на край кровати, и немного побледнев, видимо память вернула его в Афганистан, продолжил...

День, 14 февраля 1986 года, я никогда не забуду. Духи постоянно нас обстреливали с «зелёнки». Когда мина летит, она свистит. А когда исходит сигнал как разрыв воздуха - то это значит, что она взорвалась в метрах 5-10, и если удастся, как говорится, увернуться, то спасёшься. Первое время душманы стреляли штук по 10-15 подряд по нам, и мы залегали... А через месяц они вычислили нашу тактику: запустят 4 мины (в это затишье мы начинаем передвигаться), и в этот момент они досылают вдогонку ещё несколько снарядов. Надо сказать, многие наши ребята попадались на эту уловку. Так и случилось с Димкой. При обстреле нашей точки я заскочил в свой БТР и услышал по рации 21, поглядел в прицел и увидел, что у второго взвода начались передвижения, завёлся БТР, на который погрузили раненого, и он поехал в бригаду. По связи спросил: «Кто?», - в ответ: - «Димка Бушов».

До бригады его не довезли. Рана была очень серьёзная. Он скончался по дороге. 
За проявленные мужество и отвагу он был награжден орденом Красной Звезды (посмертно).

Руководитель ВПК «Гранит»,
ПДО ВКК МБУ ДО ГДДЮТ
и РО ДОСААФ России Свердловской области,
Магистр педагогических наук,
Кавалер ордена «За заслуги» ДОСААФ РФ ІІ степени
Спещ.корреспондент «Федеральной газеты 24», г.Москва
Сидлецкий Д.М.

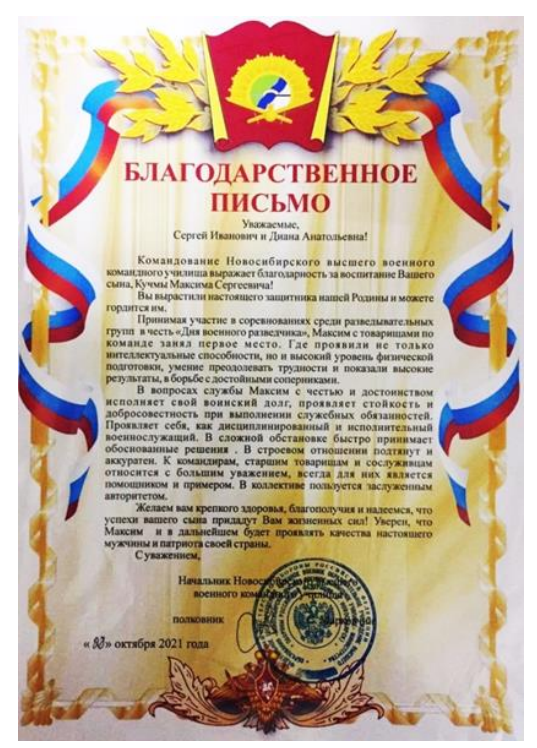

Рис. 5. Благодарственное письмо опекунам воспитанника ВПК «Гранит» Кучмы М.С.

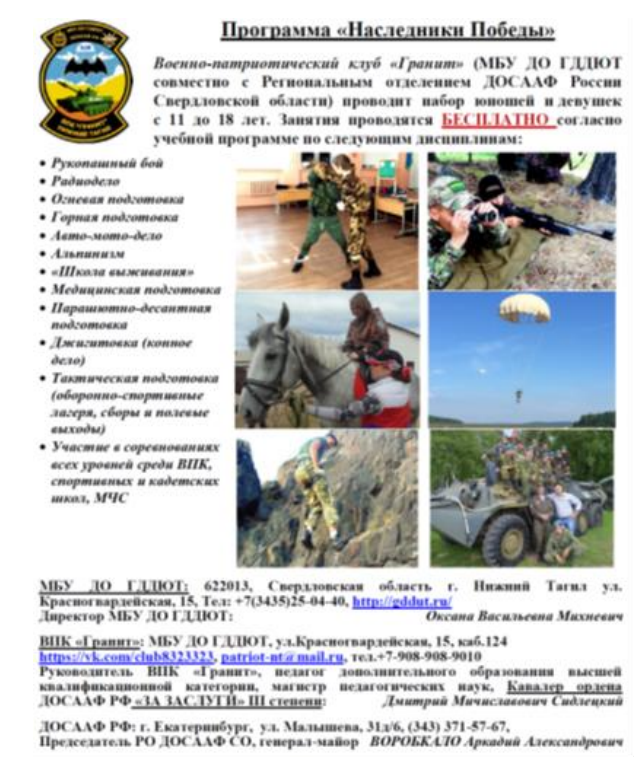

Рис. 6. Учебная программа ВПК «Гранит» 
Встречи с живыми участниками той войны в Афганистане делают подростков более собранными на жизненном пути и подготовленными к службе в Вооружённых Силах России, а точнее настоящими защитниками нашего Отечества. Примером этому может послужить «Благодарственное письмо» от Командования Новосибирского высшего военного командного училища опекунам нашего воспитанника Кучмы Максима Сергеевича, который занимался в ВПК «Гранит» четыре года (рис. 5). И это не единственная благодарность в адрес родителей и опекунов, а значит, воспитательный процесс в учебной программе ВПК «Гранит» находится на правильном пути (рис. 6). 